\title{
Pengaruh Umur dan Sumber Informasi Remaja Putri terhadap Kesehatan Alat Reproduksi di Desa Atong Kecamatan Montasik Aceh Besar
}

\author{
Influence of Age, and Information Sources for Young Women Against \\ Reproductive Health in the Atong Village of Montasik District Aceh Besar
}

\author{
Raudhatun Nuzul ZA." ${ }^{*}$, Rahmayani \\ ${ }^{1}$ Program Studi D-IV Bidan Pendidik, Universitas Ubudiyah Indonesia, Banda Aceh, Indonesia \\ ${ }^{2}$ Program Studi Ilmu Kesehatan, Universitas Serambi Mekkah, Banda Aceh, Indonesia. \\ *Korespondensi Penulis: raudhatun@uui.ac.id
}

\begin{abstract}
Abstrak
Berdasarkan hasil studi pendahuluan, jumlah remaja putri di Desa Atong tahun 2015 ada 135 remaja yang terbagi ke dalam 43 remaja awal, 42 remaja tengah, dan 50 remaja akhir, kemudian penulis mewawancarai 8 remaja putri, ada 2 remaja yang mengetahui sedikit memahami bagaimanacaranya menjaga kesehatan alat reproduksi, sedangkan 6 remaja orang lainnya tidak memahami tentang kesehatan reproduksi karena usia remaja nya yang masih muda dan juga informasi tentang kesehatan reproduksi jarang didapatkan. Penelitian ini bersifat analitik dengan pendekatan Cross cectional. Populasi adalah remaja dengan total sampel 56 orang. Pengumpulan data dilakukan dengan menyebarkan kuesioner. Kemudian diuji statistik mengunakan $C h$-quare, Ho ditolak jika $P$ value $>0,05$ dan Ha diterima jika $P$ value $<0,05$. Hasil Penelitian menunjukan bahwa dari keseluruhan 40 remaja awal/tengah sebagian besar yaitu 34 orang $(87,5 \%)$ kurang kesehatan alat reproduksi dengan nilai $P$ value 0,000 , serta dari 44 responden yang tidak pernah mendapatkan informasi sebagian besar kurang kesehatan alat reproduksi sebanyak 39 orang $(88,6 \%)$ dengan nilai $P$ value 0,031 . Ada pengaruh umur dan sumber informasi remaja putri terhadap kesehatan alat reproduksi. Untuk itu diharapkan remaja putri bias mengerti bagaimana cara menjaga kesehatan alat reproduksi dan menerapkan dalam kehidupan sehari-hari, sehingga alat reproduksi remaja terhindar dari berbagai macam penyakit.
\end{abstract}

Kata Kunci: Kesehatanalatreproduksi, Umur dan Sumber Informasi

\begin{abstract}
Abstrak
Based on the results of the preliminary study, the number of adolescent girls in Atong Village in 2015 was 135 adolescents divided into 43 early adolescents, 42 middle-aged, and 50 late adolescents, then the author interviewed 8 young women, 2 teenagers who knew little about how maintaining reproductive health, while 6 other teenagers do not understand reproductive health because of their young age and information about reproductive health is rarely found. This study is analytical with a cross-sectional approach. The population is teenagers with a total sample of 56 people. Data collection is done by distributing questionnaires. Then tested using Chi-square statistics, Ho was rejected if $P$ value $>0.05$ and Ha was accepted if $P$-value $<0.05$. Research Results: showed that from a total of 40 early/middle teens most were 34 people $(87.5 \%)$ lacking reproductive health with a value of 0,000. As well as 44 respondents who had never received information were mostly lacking reproductive health as many as 39
\end{abstract}


people (88.6\%) with a $P$ value of 0.031. There is an influence on the age and information source of young women on reproductive health. For this reason, it is expected that young women can understand how to maintain reproductive health and apply it in daily life so that the reproductive organs of young people avoid various diseases.

Keywords: Reproductive health, age and source of information

\section{PENDAHULUAN}

Kesehatan reproduksi merupakan masalah yang penting untuk mendapatkan perhatian terutama dikalangan remaja. Masa remaja diwarnai oleh pertumbuhan, perubahan, munculnya berbagai kesempatan, dan sering kali mendapati resiko-resiko kesehatan reproduksi. Kegiatan-kegiatan seksual menempatkan remaja pada tantangan resiko terhadap berbagai masalah kesehatan reproduksi. Resiko kesehatan reproduksi ini dipengaruhi oleh berbagai faktor yang saling berhubungan, misalnya tuntutan untuk menikah muda dan hubungan seksual, akses terhadap pendidikan dan pekerjaan, kurangnya perhatian terhadap kebersihan organ reproduksi, ketidaksetaraan jender, kekerasan seksual, dan pengaruh media massa maupun gaya hidup (BKKBN, 2008).

Remaja putri merupakan kelompok yang paling rentan dalam menghadapi masalah kesehatan sistem reproduksinya. Hal ini dikarenakan secara anatomis, remaja putri lebih mudah terkena infeksi dari luar karena bentuk dan letak organ reproduksinya yang dekat dengan anus. Dari segi fisiologis, remaja putri akan mengalami menstruasi, sedangkan masalah-masalah lain yang mungkin terjadi adalah kehamilan di luar nikah, aborsi, dan perilaku seks di luar nikah yang beresiko terhadap kesehatan alat reproduksinya. Dari segi sosial, remaja putri sering mendapatkan perlakukan kekerasan seksual (BKKBN, 2008).

Di dunia, angka kejadian akibat infeksi alat reproduksi diperkirakan sekitar 2,3 juta pertahun 1,2 juta diantaranya ditemukan dinegara berkembang,sedangkan jumlah penderita baru sekitar 5 juta pertahun dan terdapat dinegara berkembang sekitar 3 juta (BKKBN, 2008).

Di Indonesia pelayanan kesehatan reproduksi mencakup 4 komponen esensial yang mampu memberikan hasil yang efektif dan efisien. Adapun 4 komponen antara lain Pelayanan Kesehatan Reproduksi Esensial (PKRE) yaitu Kesehatan Ibu dan Bayi Baru Lahir,Keluarga Berencana, Kesehatan Reproduksi Remaja (KRR) dan pencegahan atau penanggulangan penyakit menular seksual (PMS) temasuk HIV/AIDS. Beberapa penyakit ginekologi dan gangguan kesehatan reproduksi perempuan merupakan suatu masalah serius dalam masyarakat seperti kemandulan, keputihan, dan kanker rahim (Andira, 2010). 
Di negara maju insiden terjadinya infeksi 87 per 100.000 angka kematiannya kira kira 27 per 100.000. Data terbaru berdasarkan penelitian pada 13 laboratorium patologi anatomi di Indonesia menempatkan kanker serviks diurutan pertama dengan perevaluasi 18,62 $\%$ disusul kanker payudara 11,22 \% dan kanker kulit menurunkan resiko kehamilan dan pengguguran yang tidak aman, menurunkan penularan IMS/HIV-AIDS, memberikan informasi kontrasepsi dan konseling untuk mengambil keputusan sendiri tentang kesehatan reproduksi (Soetjiningsih, 2010).

WHO (Worl Health Organitation) mendefinisikan remaja bila anak telah mencapai umur 12-24 tahun.Menurut Depkes RI (2008) adalah antara 10-19 tahun dan belum kawin, sedangkan menurut Badan Kependudukan dan Keluarga Berencana Nasional (BKKBN) adalah 10-19 tahun (Widiastuti, 2009). Resiko kesehatan reproduksi ini dipengaruhi oleh beberapa faktor yang saling berhubungan misalnya kebersihan organ-organ reproduksi, hubungan seksual pranikah, akses terhadap pendidikan kesehatan, kekerasan seksual, pengaruh media masa, gaya hidup yang bebas, akses terhadap pelayanan kesehatan reproduksi yang terjangkau, dan kurangnya informasi yang didapatkan remaja akibat umur mereka yang masih lebih muda (Andrew, 2009). Beberapa penyakit infeksi pada alat reproduksi wanita adalah trikomoniasis,vaginosis bacterial, kandidiadis, vulvovaginitis, gonore, klamida dan sifilis. Salah satu gejala dan tanda-tanda penyakit infeksi alat reproduksi wanita adalah terjadinya keputihan. Keputihan merupakan salah satu masalah yang sejak lama menjadi persoalan bagi kaum wanita. Keputihan adalah cairan berlebih yang keluar dari vagina (Kliegman, 2007).

Berdasarkan hasil studi pendahuluan, jumlah remaja putri di Desa Atong tahun 2015 ada 135 remaja yang terbagi kedalam 43 remaja awal, 42 remaja tengah, dan 50 remaja akhir,kemudian penulis mewawancarai 8 remaja putri, ada 2 remaja yang mengetahui sedikit memahami bagaimanacaranya menjaga kesehatan alat reproduksi, sedangkan 6 remajaorang lainnya tidak memahami tentang kesehatan reproduksi karena usia remaja nya yang masih muda dan juga informasi tentang kesehatan reproduksi jarang didapatkan.

Berdasarkan latar belakang yang telah peneliti uraikan diatas, maka dapat dirumuskan masalahnya yaitu "Pengaruh umur dan sumber informasi remaja putri terhadap kesehatan alat reproduksi di Desa Atong Kecamatan Montasik Kabupaten Aceh Besar”. 


\section{METODE PENELITIAN}

Jenis penelitian yang dilakukan adalah analitik dengan pendekatan crossectional. Tekhnik Pengumpulan Data menggunakan data primer dan sekunder. Populasi dalam penelitian adalah seluruh remaja putri berjumlah 135 orang. Tekhnik pengambilan sampel proporsional sampling sampling yaitu mengambil sebagian sampel dari keseluruhan objek yang akan diteliti. (Notoatmodjo,2010). Jumlah besar sampel adalah 57 orang dengan memakai kriteria inklusi dan ekslusi. Dilakukan dengan analisa statistik uji chi-square.

\section{HASIL DAN PEMBAHASAN}

Tabel 1. Distribusi Frekuensi Berdasarkan Kesehatan Alat Reproduksi di Desa Atong Kecamatan Montasik Kabupaten Aceh Besar

\begin{tabular}{llccc}
\hline No & \multicolumn{2}{c}{ Kesehatan alat reproduksi } & f & \% \\
\hline 1 & Baik & 17 & $30,4 \%$ \\
2 & \multirow{2}{*}{ Kurang } & 39 & $69,6 \%$ \\
\hline & & Jumlah & $\mathbf{5 6}$ & $\mathbf{1 0 0}$ \\
\hline
\end{tabular}

Berdasarkan Tabel 1 menunjukkan bahwa dari 56 responden, dapat dilihat bahwayang kurang terhadap kesehatan alat reproduksi sebanyak 39 orang $(69,6 \%)$.

Tabel 2. Distribusi Frekuensi Berdasarkan Umur di Desa Atong Kecamatan Montasik Kabupaten Aceh Besar

\begin{tabular}{clccc}
\hline No & \multicolumn{1}{c}{ Umur } & f & \% \\
\hline 1 & Remaja awal/tengah & 40 & $71,4 \%$ \\
2 & Remaja akhir & 16 & $28,6 \%$ \\
\hline \multicolumn{2}{r}{ Jumlah } & $\mathbf{5 6}$ & $\mathbf{1 0 0}$ \\
\hline
\end{tabular}

Berdasarkan Tabel 2 menunjukkan bahwa dari 56 responden, dapat dilihat bahwa yang remaja awal/tengah sebanyak 40 orang $(71,4 \%)$.

Tabel 3. Distribusi Frekuensi Berdasarkan Sumber Informasi di Desa Atong Kecamatan Montasik Kabupaten Aceh Besar

\begin{tabular}{ccccc}
\hline No & & Sumber informasi & f & \% \\
\hline 1 & Pernah & & 12 & $21,4 \%$ \\
2 & Tidak pernah & & 44 & $78,6 \%$ \\
\hline & & Jumlah & $\mathbf{5 6}$ & $\mathbf{1 0 0}$ \\
\hline
\end{tabular}


Berdasarkan Tabel 3 menunjukkan bahwa dari 56 responden, yang tidak pernah mendapatkan informasi sebanyak 44 orang $(78,6 \%)$.

Tabel 4. Pengaruh Umur Terhadap Kesehatan Alat Reproduksi di Desa Atong Kecamatan Montasik Kabupaten Aceh Besar

\begin{tabular}{|c|c|c|c|c|c|c|c|c|}
\hline \multirow{3}{*}{ No } & \multirow{3}{*}{ Umur } & \multicolumn{6}{|c|}{ Kesehatan Alat Reproduksi } & \multirow{3}{*}{ P-Value } \\
\hline & & \multicolumn{2}{|c|}{ Baik } & \multicolumn{2}{|c|}{ Kurang } & \multicolumn{2}{|c|}{ Total } & \\
\hline & & $\mathbf{f}$ & $\%$ & $\mathbf{f}$ & $\%$ & Jlh & $\%$ & \\
\hline 1 & Remaja awal/tengah & 5 & 12,5 & 35 & 87,5 & 40 & 100 & \multirow{3}{*}{0,000} \\
\hline 2 & Remaja akhir & 12 & 75 & 4 & 25 & 16 & 100 & \\
\hline & Total & 17 & & 39 & & 56 & 100 & \\
\hline
\end{tabular}

Berdasarkan Tabel 4.4 diatas dapat dilihat bahwa dari 40 remaja awal/tengah sebagian besar yaitu 35 orang $(87,5 \%)$ kurang terhadap kesehatan alat reproduksi. Berdasarkan uji stastistik didapatkan nilai $P$ value $=0.000,<\alpha=0,05$ sehingga dapat disimpulkan bahwa ada pengaruh umur terhadap kesehatan alat reproduksi di Desa Atong Kecamatan Montasik Kabupaten Aceh Besar.

Tabel 5. Pengaruh Sumber Informasi Terhadap Kesehatan Alat Reproduksi di Desa Atong Kecamatan Montasik Kabupaten Aceh Besar

\begin{tabular}{|c|c|c|c|c|c|c|c|c|}
\hline \multirow{3}{*}{ No } & \multirow{3}{*}{$\begin{array}{l}\text { Sumber } \\
\text { informasi }\end{array}$} & \multicolumn{6}{|c|}{ Kesehatan Alat Reproduksi } & \multirow{3}{*}{ p-Value } \\
\hline & & \multicolumn{2}{|c|}{ Baik } & \multicolumn{2}{|c|}{ Kurang } & \multicolumn{2}{|c|}{ Total } & \\
\hline & & $\mathbf{f}$ & $\%$ & $\mathbf{f}$ & $\%$ & Jlh & $\%$ & \\
\hline 1 & Pernah & 7 & 58,3 & 5 & 41,7 & 12 & 100 & \multirow{3}{*}{0,031} \\
\hline 2 & Tidak Pernah & 10 & 22,7 & 34 & 77,3 & 44 & 100 & \\
\hline & Total & 17 & & 39 & & 56 & 100 & \\
\hline
\end{tabular}

Berdasarkan Tabel 5 di atas dapat dilihat bahwa dari 44 responden yang tidak pernah mendapatkan informasi ada 34 orang $(77,3 \%)$ yang kurang kesehatan alat reproduksi. Berdasarkan uji stastistik didapatkan nilai $P$ value $=0.031, \quad<\alpha=0,05$ sehingga dapat disimpulkan bahwa ada pengaruh sumber informasi terhadap kesehatan alat reproduksi di Desa Atong Kecamatan Montasik Kabupaten Aceh Besar. 


\section{Pembahasan}

1. Pengaruh umur terhadap kesehatan alat reproduksi

Berdasarkan Tabel 4.4 diatas dapat dilihat bahwa dari 40 remaja awal/tengah sebagian besar yaitu 35 orang $(87,5 \%)$ kurang terhadap kesehatan alat reproduksi. Berdasarkan uji stastistik didapatkan nilai $P$ value $=0.000,<\alpha=0,05$ sehingga dapat disimpulkan bahwa ada pengaruh umur terhadap kesehatan alat reproduksi di Desa Atong Kecamatan Montasik Kabupaten Aceh Besar. Pengertian kesehatan reproduksi adalah suatu keadaan kesehatan yang sempurna baik secara fisik, mental, dan sosial dan bukan semata-mata terbebas dari penyakit atau kecacatan dalam segala aspek yang berhubungan dengan sistem reproduksi, fungsi serta prosesnya. Sedangkan kesehatan reproduksi menurut WHO adalah suatu keadaan fisik, mental dan sosial yang utuh, bukan hanya bebas dari penyakit atau kecacatan dalam segala aspek yang berhubungan dengan sistem reproduksi, fungsi serta prosesnya (BKKBN, 2008).

Remaja merupakan individu yang sedangmengalami perkembangan menuju kedewasaan. Mereka adalah anak-anak yang telah meninggalkan usia 11 tahun dan menuju usia 21 tahun. Batasan ini tentunya tidakbersifat absolut, sebab sering terjadi perbedaan angka usia yang dapat disebabkan oleh terjadinya perbedaan proses pematangan yang diperoleh. Masa remaja adalah suatu bagian dari proses tubuh kembang yang berkesinambungan, yang merupakan masa peralihan dari kanak-kanak ke dewasa muda (Moeliono, 2007). Hal ini didukung pula oleh penelitian Prihatiningsih D (2008), yang berjudul pengaruh pemberian pendidikan kesehatan terhadap tingkat pengetahuan dan umur remaja di Kelurahan Ngupasan wilayah kerja puskesmas Gondomanan Yogyakarta dimana terdapat pengaruh yang signifikan antara pengetahuan dan umur remaja dengan pemberian pendidikan dengan nilai $P$ value $=0.024$.

Peneliti berasumsi masa remaja awal/tengah ditandai dengan peningkatan yang cepat dari pertumbuhan dan pematangan fisik. Masa remaja menengah ditandai dengan hampir lengkapnya pertumbuhan pubertas, dan keinginan untuk memperbaiki emosional dan psikologis dengan orang tua. Masa remaja akhir ditandai dengan persiapan untuk peran sebagai seorang dewasa. Pada usia remaja akhir, remaja telah mengetahui mana yang terbaik untuk memperhatikan kesehatannya terutama kesehatan reproduksi dalam kehidupan sehari-hari. Oleh karena itu usia remaja sangat mempengaruhi peningkatan pengetahuan remaja tentang kesehatan alat reproduksi. 
2. Pengaruh sumber informasi terhadap kesehatan alat reproduksi

Berdasarkan Tabel 4.5 diatas dapat dilihat bahwa dari 44 responden yang tidak pernah mendapatkan informasi ada 34 orang (77,3\%) yang kurang kesehatan alat reproduksi. Berdasarkan uji stastistik didapatkan nilai $P$ value $=0.031,<\alpha=0,05$ sehingga dapat disimpulkan bahwa ada pengaruh sumber informasi terhadap kesehatan alat reproduksi di Desa Atong Kecamatan Montasik Kabupaten Aceh Besar.

Kesehatan reproduksi adalah suatu keadaan sehat, secara menyeluruh mencakup fisik, mental dan kedudukan sosial yang berkaitan dengan alat, fungsi serta proses reproduksi, dan pemikiran kesehatan reproduksi bukan hanya kondisi yang bebas dari penyakit, melainkan juga bagaimana seseorang dapat memiliki seksual yang aman dan memuaskan sebelum dan sudah menikah (Andira, 2010).

Masa remaja berlangsung melalui 3 tahapan yang masing-masing ditandai dengan isu-isu biologik, psikologik dan sosial, yaitu: masa remaja awal (10-14 tahun), menengah (15-16 tahun) dan akhir (17-20 tahun). Faktor-faktor yang mempengaruhi keadaan kesehatan reproduksi remaja adalah faktor internal antara lain pengetahuan, umur,kepribadian remaja itu sendiri dan faktor eksternal yaitu lingkungan dimana remaja berada mempengaruhi kegiatan seksual remaja yang beresiko terhadap masalah kesehatan reproduksi. Sumber informasi eksternal yang mudah mereka jangkau adalah teman-teman sebaya (peer group), bacaan-bacaan popular, VCD porno, akses internet, dan lainlain.Sumber informasi eksternal ini tidak selalu benar, terbaik dan bermutu. (Moeliono, 2007).

Dari hasil penelitian sebelumnya yang dilakukan oleh Achyar (2008) tentang informasi kesehatan alat reproduksi yang didapatkan remaja memang sangat minim sekali. Remaja perlu diberikan pendidikan mengenai kesehatan reproduksi itu sendiri. Dalam penyampaian pendidikan mengenai kesehatan reproduksi kepada remaja ternyata peranan peer group sangat berpengaruh, dan ada peningkatan pengetahuan. Remaja perlu mendapatkan pembinaan tentang kesehatan reproduksi secara intensif dan berkesinambungan di tingkat Puskesmas, serta monitoring dan evaluasi program pemberdayaan peer group yang dilakukan oleh Dinas Kesehatan Kabupaten.

Peneliti berasumsi bahwa sumber informasi yang didapatkan remaja sangat berpengaruh terhadap pengetahuan kesehatan alat reproduksi yang diterimannya. Remaja harus memiliki informasi internal dan eksternal yang benar karena sumber informasi 
tersebut mempengaruhi remaja untuk menjaga kesehatan alat reproduksinya. Jika sumber informasi yang didapatkan tidak benar maka akan menimbulkan masalah kesehatan reproduksi pada remaja.

\section{KESIMPULAN}

Ada pengaruh umur terhadap kesehatan alat reproduksi dengan nilai $P$ value 0,000 di Desa Atong Kecamatan Montasik Kabupaten Aceh Besar. Ada pengaruh sumber informasi terhadap kesehatan alat reproduksi dengan nilai $P$ value 0,031 di Desa Atong Kecamatan Montasik Kabupaten Aceh Besar.

\section{SARAN}

Diharapkan untuk institusi pendidikan bisa berguna untuk bahan tambahan referensi dalam mengadakan atau melanjutkan penelitian mahasiswa dimasa yang akan datang.

\section{DAFTAR PUSTAKA}

Atikah. (2009). Gizi Untuk Kebidanan Cetakan Pertama Penerbit Nuha Medika

Almatsir. (2009). Gizi Untuk Kebidanan Cetakan Pertama Penerbit Nuha Medika

Adisasmito. (2008). Catatan perkembangan posyandu.Diakses dari http://arali2008. wordpress.com/2009/04/20/catatan-ringan-tentang-perkembangan posyandu/.

Budiarto.(2009). Biostatistik untuk kedokteran dan Kesehatan masyarakat. Jakarta: EGC

Bapeda Jabar. (2006) Status Gizi Buruk Di Jabar. Dikutip dalam http://www.depkes_jabar.go.id(tanggal 21 Januari 2015).

Dinkes Aceh. (2013). Hasil Survei data dukung gizi provinsi nanggroe aceh darussalam tahun 2013.

Depkes RI. (2005). Balita BGM. http//:www.bank.data.depkes.go.id. 2010. Buku Ajaran Gizi untuk Kebidanan. Jogjakarta: Nuha Meidka

Hasdi. (2009). Revilitasi posyandu. Diakses dari http://skripsi-fkm. blogspot. com/2009/04/revitalisasi-posyandu_25. html.pada tanggal 04 Februari 2015.

Heru, S.A. (2007). Kader kesehatan masyarakat. Jakarta: EGC

Hidayat, A. (2007). Pengantar ilmu kesehatan anak untuk pendidikan kebidanan. Jakarta: Salemba Medika.

Kemenkes RI, Direktorat Bina Gizi. (2011). Standar antropometri penilaian status gizi anak. Jakarta. 
Khairunisa. (2013). Hubungan peran aktif ibu dalam kegiatan posyandu dengan status gizi balita di wilayah kerja Puskesmas Kuta Baro Aceh Besar.

Notoatmodjo, S. (2005). Metodelogi Penelitian Kesehatan. Jakarta: Rineka Cipta.

Notoamodjo, S. (2007). Prinsip-prinsip dasar ilmu kesehatan masyarakat, Jakarta: Rineka Cipta.

Notoatmodjo, S. (2007). Pendidikan dan perilaku kesehatan, Jakarta: Rineka Cipta.

Maulana. (2009). Hubungan Keaktifan Ibu Dalam Posyandu Dengan Penurunan Jumlah Balita Bawah Garis Merah (Bgm) Di Desa Suko Jember Kecamatan Jelbuk Kabupaten Jember.

Peter Stalker. (2008). Millennium Development Goals. Jakarta.

Profil Kesehatan Kab.Bandung Tahun. (2006). Gizi Bayi dan Balita. Dikutip dalam http://www.puslitbangbandung.go.id (Tanggal 23 Januari 2015).

Pulisbang Gizi Bogor. (2007). Kejadian kasus gizi KEP, Bogor.

Proverawati. (2009). Gizi Untuk Kebidanan Cetakan Pertama Penerbit Nuha Medika

Riskesdas. (2011). Data Status Gizi Indonesia.

Radiansyah. (2007). Gizi Balita dalam http://www.radiansyah.com/gizi/balita (dikutip tanggal 30 Januari 2015).

Syakira. (2009). Tentang posyandu.Diakses dari http://syakira-blog.blogspot.com /2009/01/ tentang-posyandu.html.

Sediaoetama. (2006). Gizi.Jakarta: Rineka Cipta , Jakarta

Suparianto. (2012). Konsep Dasar Status Gizi Balita: dikutip dalam http://blogspot.com (tanggal 21 Januari 2015)

Supariasa, dkk. (2008). Penilaian Status Gizi.EGC. Jakarta.

Ulie Midwife. (2012). “ Posandu sebagai Saran Peran Serta Masyarakat dalam Usaha Peningkatan Kesehatan Masyarakat”. Makalah. Universitas. 